\title{
Revisiting Michael Bonell's humid tropical rainforest catchments: isotope tracers reveal seasonal and inter-annual shifts in catchment hydrology
}

\author{
Hanshe Lim ${ }^{1}$, Niels Munksgaard ${ }^{2}$, Xi Zhou ${ }^{3}$, and Michael Bird ${ }^{2}$ \\ ${ }^{1}$ James Cook University College of Science and Engineering \\ ${ }^{2}$ James Cook University \\ ${ }^{3}$ Beijing Information Science and Technology University
}

January 29, 2022

\begin{abstract}
It has been almost 50 years since Mike Bonell's foundational work in the humid tropics, kickstarting the field of tropical hydrology. In order to expand on this work and build a more generalized hydrological understanding of steep rainforest catchments, we studied the seasonal and inter-annual evolution of hydrological response from two catchments with similar characteristics to those studied by Bonell. Both hydrometric and water stable isotope data were collected at relatively high frequencies during one wet season (Thompson Creek) and a three-year period (Atika Creek). The longer dataset spans a wide range of environmental conditions experienced in the humid tropics, including events that cover the wetting-up transitional period of the wet season, ENSO events and tropical cyclones. Both catchments displayed fast streamflow response to rainfall with the shallow upper soil profile responding quickly to rainfall at Atika Creek. New findings from this study include the importance of pre-event water $(>50 \%)$ for overall event flows, especially when the catchment was wet. Rainfall, surface runoff and groundwater isotope compositions varied between rainfall events with the most complex mixing plots observed for multipeak events that occurred at the start of the wet season and after a dry period within the wet season. Inter-annual variability in catchment hydrology reflected changing ENSO conditions and the 2020-21 La Ninã wet season was characterized by several tropical cyclone events which generated the most 180-depleted rainfall and streamflow isotope values. Our findings highlight the requirement for high frequency multi-source sampling to accurately interpret catchment behavior. We propose a conceptual model to describe the seasonal evolution of streamflow response in steep rainforest catchments.
\end{abstract}

\section{Hosted file}

AC HP draft_1.docx available at https://authorea.com/users/457951/articles/554581-revisitingmichael-bonell-s-humid-tropical-rainforest-catchments-isotope-tracers-reveal-seasonaland-inter-annual-shifts-in-catchment-hydrology

\section{Hosted file}

TABLES.docx available at https://authorea.com/users/457951/articles/554581-revisitingmichael-bonell-s-humid-tropical-rainforest-catchments-isotope-tracers-reveal-seasonaland-inter-annual-shifts-in-catchment-hydrology

\section{Hosted file}

FIGURES.docx available at https://authorea.com/users/457951/articles/554581-revisitingmichael-bonell-s-humid-tropical-rainforest-catchments-isotope-tracers-reveal-seasonaland-inter-annual-shifts-in-catchment-hydrology 